iterarische Zusammenarbeit 



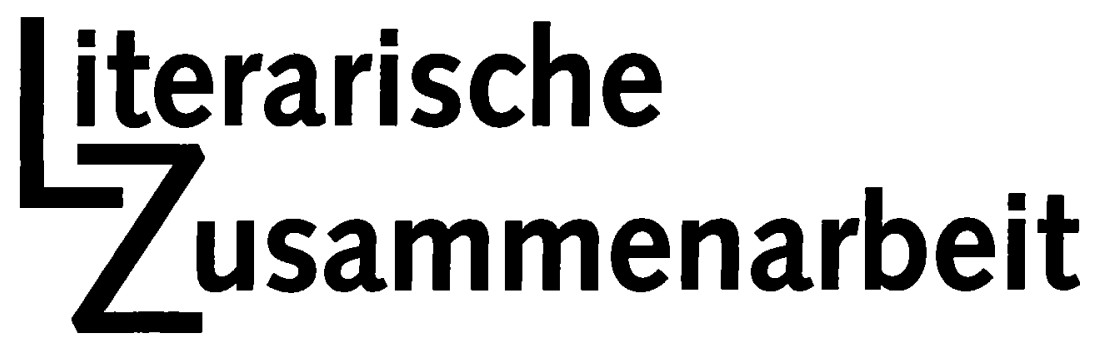

Herausgegeben von

Bodo Plachta

Max Niemeyer Verlag

Tübingen 2001

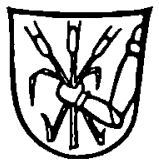


Die Deutsche Bibliothek - CIP-Einheitsaufnahme

Literarische Zusammenarbeit / hrsg. von Bodo Plachta. - Tübingen: Niemeyer, 2001

\section{ISBN 3-484-10825-8}

(C) Max Niemeyer Verlag GmbH, Tübingen 2001

Das Werk einschließlich aller seiner Teile ist urheberrechtlich geschützt. Jede Verwertung außerhalb der engen Grenzen des Urheberrechtsgesetzes ist ohne Zustimmung des Verlages unzulässig und strafbar. Das gilt insbesondere für Vervielfältigungen, Übersetzungen, Mikroverfilmungen und die Einspeicherung und Verarbeitung in elektronischen Systemen.

Printed in Germany.

Gedruckt auf alterungsbeständigem Papier.

Druck: Gulde-Druck GmbH, Tübingen

Buchbinder: Geiger, Ammerbuch 